\title{
Empreendedorismo e profissionais da informação
}

\section{Entrepreneurship and information professionals}

\author{
Daniela Fernanda Assis de Oliveira Spudeit ${ }^{1}$ \\ ${ }^{1}$ Universidade do Estado de Santa Catarina, UDESC, Florianópolis, SC, Brasil
}

Autor para correspondência/Mail to: Daniela Fernanda Assis de Oliveira Spudeit (danielaspudeit@gmail.com)

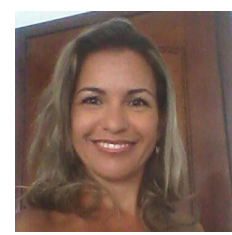

Daniela Fernanda Assis de Oliveira Spudeit é professora no Curso de Graduação em Biblioteconomia e no Programa de Pós-Graduação de Gestão da Informação da Universidade do Estado de Santa Catarina (UDESC). Possui mestrado em Ciência da Informação pela UFSC, especialização em Gestão de Unidades de Informação pela UDESC, especialização em Didática do Ensino Superior pelo SENAC, bacharelado em Biblioteconomia pela UFSC e licenciatura em Pedagogia pela UDESC. Atualmente coordena o Grupo de Bibliotecários da Área Escolar em Santa Catarina (GBAESC), é vice-presidente da Associação Brasileira de Educação em Ciência da Informação (ABECIN) e editora da Revista Brasileira de Educação em Ciência da Informação (REBECIN).

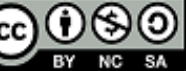

Copyright (c) 2017 Spudeit, D. F. A. O.. Todo o conteúdo da Revista (incluindo-se instruções, política editorial e modelos) está sob uma licença Creative Commons Atribuição-NãoComercial-Compartilhalgual 3.0 Não Adaptada. Ao serem publicados por esta Revista, os artigos são de livre uso em ambientes educacionais, de pesquisa e não comerciais, com atribuição de autoria obrigatória. Mais informações em http://revistas.ufpr.br/atoz/about/submissions\#copyrightNotice.

\begin{abstract}
Resumo
A mestre em Ciência da Informação (UFSC), Daniela Spudeit responde questões relacionadas ao empreendedorismo e profissionais de informação, as relações entre o empreendedorismo, inovação, e gestão do conhecimento, apresentando exemplos e explorando o impacto das tecnologias na atividade, assim como as condições atuais do ensino para a formação de profissionais empreendedores.
\end{abstract}

Palavras-chave: Empreendedorismo; Profissionais de informação

\begin{abstract}
Daniela Spudeit, Master in Information Science (UFSC), answers questions about entrepreneurship and information professionals, related with the correlation between entrepreneurship, innovation and knowledge management, providing examples and exploring the impact of technology in the profesional activity, as well as the teaching-learning conditions focused on training entrepreneurial professionals.
\end{abstract}

Keywords: Entrepreneurship; information professionals

\section{Como os diferentes tipos de empreendedorismo se aplicam à atuação dos profissionais de informação?}

Pela literatura é possível encontrar vários tipos de empreendedorismo, como o empreendedor por necessidade, por inovação, por oportunidade, empreendedor social, cultural, intraempreendedorismo, entre vários outros. Todos esses acima citados se enquadram na atuação dos profissionais da informação. O mais comum é o empreendedor por oportunidade, bem característico dos países em desenvolvimento como Brasil e Índia, esse profissional começa a empreender a partir da percepção de uma oportunidade de negócio, um nicho de atuação ainda não explorado, o que move esse profissional não é a necessidade, mas sim uma motivação de encontrar uma solução, o desafio de achar solução para algum problema. Na nossa área também é bem comum o empreendedorismo social que é aquele que não está preocupado com o lucro que pode gerar, mas sim num bem maior, no coletivo, está focado em ações que podem trazer benefícios para a comunidade como é o caso de bibliotecas comunitárias (como a Barca dos Livros em Florianópolis), iniciativas independentes (como o projeto Biblioteca Sem Paredes do Rio de Janeiro), ações do terceiro setor por meio de Ongs que promovem acesso à informação e educação, ações de leitura, entre outras sem fins lucrativos como exemplo Instituto Guga Kuerten e Fundação Ayrton Senna. Destaco aqui também a iniciativa da ONG de John Wood (Leia a história dele no livro "Saí da Microsoft para mudar o mundo") que cria bibliotecas em todas as partes do mundo para promover acesso à leitura e informação. Tem também o intraempreendedorismo bem comum na nossa área. São aqueles profissionais que são funcionários públicos ou de empresas privadas, mas que tem um perfil diferenciado, são ousados, inovadores, pensam fora da caixa, captam recursos, estabelecem parcerias, tem visão sistêmica e atuam colaborativamente em equipes interdisciplinares, vestem a camisa da empresa como se fosse seu próprio negócio. Tem iniciativa, proatividade, buscam soluções e fazem a diferença no local onde atuam.

\section{Quais as relações existentes entre inovação e gestão do conhecimento?}

A GC ocorre no momento em que as pessoas atuam colaborativamente absorvendo informações e transformando em conhecimento aliado às experiências, valores, percepções. A geração do conhecimento proposta por Davenport e Prusak (1998) e a teoria da criação do conhecimento proposta por Nonaka e Takeuchi (1997) dão subsídios para esses processos. Por meio destes processos, é possível dar base para as pessoas identificarem, codificarem e compartilharem o conhecimento de forma estratégica em suas organizações e assim promover inovação. Segundo Davenport e Prusak (1998), a inovação ocorre nas fronteiras entre as mentes e não dentro 
do território de uma só base de habilidades e conhecimento. Ao se trabalhar em projeto ou problema por meio de um grupo composto por pessoas com diferentes perspectivas, estas diferenças impedem que o grupo caia em soluções rotineiras para os problemas.

\section{Quais negócios inovadores já foram empreendidos por profissionais da informação?}

No Portal EmpreendeBiblio.com é possível encontrar vários depoimentos de profissionais que estão empreendendo em seus próprios negócios na área de gestão da informação. Embora algumas empresas tenham sido criadas na década de 1990 quando algumas oportunidades começaram a surgir, grande parte das empresas começou a partir dos anos 2000. Várias oportunidades ligadas à gestão de processos, comércio eletrônico, arquitetura da informação, gestão eletrônica de documentos, sistemas de informação, gestão do conhecimento, entre outras surgiram, os profissionais da informação perceberam essa lacuna e começaram a organizar seus negócios e suas empresas. Ainda existem muitos profissionais da informação que prestam serviços, porém não tem empresa formalizada registrada com CNPJ.

\section{Como a tecnologia afeta as condições para o empreendedorismo e a inovação no contexto das ativida- des/produtos de informação?}

Afeta diretamente porque os profissionais da informação podem usar todos os recursos tecnológicos disponíveis para promover acesso, organização, recuperação, preservação, armazenamento, divulgação e compartilhamento de informações para promover inovação e prestação de serviços de acordo com demandas percebidas.

\section{No contexto brasileiro, que fatores afetariam a intenção / motivação de jovens profissionais da informação para que se tornem empreendedores?}

Costumo dizer que a motivação é interna. Cada pessoa deve encontrar motivos para agir. Porém, os gestores devem promover uma cultura empreendedora por meio de um ambiente saudável. Podem incentivar seus colaboradores a ir além, a desenvolver um perfil intraempreenededor, ou seja, os gestores podem propiciar condições para a motivação. Isto pode ocorrer por meio de incentivos, recompensas, oportunidades para todos sugerirem e participarem dos processos de planejamento e tomada de decisão nas organizações, etc. Ainda na escola e na Universidade, os professores também tem essa responsabilidade conforme Dolabela (2004) defende. Criar mecanismos, estratégias, metodologias de ensino para desenvolver esse perfil empreendedor. Seja por meio de disciplinas específicas, projetos de ensino, extensão, pesquisas, eventos entre outras modalidades é possível motivar os profissionais da informação a identificar oportunidades e empreenderem.

\section{Como você avalia o ambiente de formação dos profissionais da informação voltado para o empreendedo- rismo e inovação (considerando conhecimentos, habilidades e atitudes)? Quais as perspectivas para o futuro?}

O futuro é propício para empreender. Em nível mundial cada vez menos oportunidades de trabalho de carteira assinada e vagas em concursos públicos serão abertas. A tendência é mudar cada vez mais as relações trabalhistas. Tanto na formação quanto na atuação é preciso buscar outros caminhos e soluções, é preciso se diferenciar, buscar capacitação contínua, conhecer novas culturas, se relacionar com profissionais de outras áreas, aprender outros idiomas, correr riscos (planejados) e estar atento às mudanças e demandas do mercado e principalmente da sociedade. Somos profissionais da informação e nosso foco deve ser as pessoas em primeiro lugar. Tecnologia e processos gerenciais são importantes, mas sem pessoas nada tem sentido, precisamos identificar as necessidades das pessoas e apresentar soluções. Nossa missão é social e temos que resgatar a veia humanística da nossa profissão. Só assim podemos fazer a diferença no mundo do trabalho e na vida das pessoas. 
Como citar esta entrevista (APA):

Spudeit, D. F. A. O. (2017). Empreendedorismo e profissionais da informação. AtoZ: novas práticas em informação e conhecimento, 6(1), 1 - ATUALIZAR. Recuperado de: http://dx.doi.org/10.5380/atoz.v6i1.54358 